\title{
The Effect of Brand Identification and Sense of Community on Brand Love (A Survey of Kaskus Trading Forum Users in Bandung)
}

\author{
Fajar Gumelar Maulana ${ }^{1, *}$ Ratih Hurriyati ${ }^{2,}$ Lili Adi Wibowo ${ }^{3,}$ Bambang \\ Widjajanta $^{4}$
}

${ }_{1}$ Universitas Pendidikan Indonesia
${ }^{2}$ Universitas Pendidikan Indonesia
${ }^{3}$ Universitas Pendidikan Indonesia
${ }^{4}$ Universitas Pendidikan Indonesia
${ }^{*}$ Corresponding author. Email: gumelarajay@gmail.com

\begin{abstract}
Online trading forums are becoming viral in Indonesia, but many failures experienced by startup companies, especially in the trading forum. Research on brand love has become a trend in several research studies in trading forum startup companies, especially in overcoming online trading forums. This study aims to determine the effect of brand identification and the sense of community on brand love in Kaskus trading forum users in Bandung. The research design of the study used was a cross-sectional method. This study employed a descriptive approach with an explanatory survey method involving 107 respondents who had been selected by using non-probability sampling. A questionnaire was used as a research instrument to collect data from respondents. The technical analysis of the study was a descriptive technique using frequency distribution. The results showed that the effect of brand identification was in the quite good category, and the sense of community on brand love was also in a good category. The novelty of this research is the difference that lies in the object of research, research time, measurement tools, literature used, theories used, and research results
\end{abstract}

Keywords: brand identification, sense of community, brand love, Kaskus.

\section{INTRODUCTION}

Brand is considered as a builder of an important profile and assets of the company [1]. Building the concept of brand love to the company aims to measure the feelings of consumer love towards the brand [2]. A love-feeling has a core of identity, but it must encompass the aspects of identity that provide power and strength [3]. Cultivating a brand love is a major concern for companies that generally popular among society [4].

Brand love was first conceptualized by [5]. An important consistency in brand loves is also to remind the personal feelings and experiences of consumers due to the instinct of self-change that determines the positive or negative direction. [6].
Data on Indonesian online trading startup companies is shown in Table 1. This information shows the state of the trading forum company. The country rank position shows that Kaskus trading forum outclasses other online trading forums.

Table 1. Companies and Trading Forums in Indonesia

\begin{tabular}{|l|l|l|}
\hline \multicolumn{1}{|c|}{ Companies } & Country Rank & Global Rank \\
\hline FJB KASKUS & 12 & 317 \\
\hline OLX & 41 & 1.296 \\
\hline Blanja.com & 126 & 7.669 \\
\hline Orami & 134 & 7.742 \\
\hline Source: [7]
\end{tabular}

Figure 1 shows the position of Kaskus within one week in October which experiences a very flat condition, where there was no increase nor decrease. 


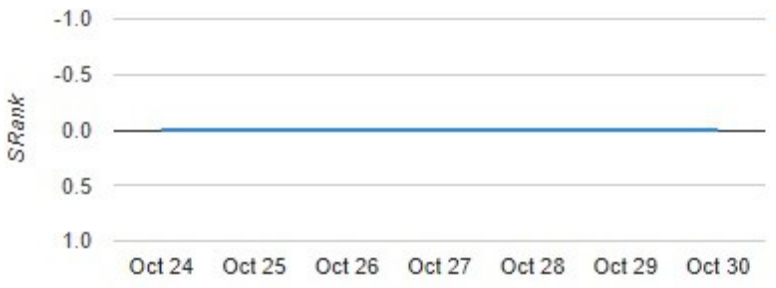

Kaskus Position in Indonesian Trading Company

A startup company needs to build a brand love so that its position is stronger in the consumer's mind [9]. Over the past few years, Kaskus has always experienced a decline in the position of the consumer's mind. Table 2 shows the position of Kaskus from 2012 to 2018, in which the percentage of Kaskus increased from 2012 to 2013, which then decreased afterwards. This shows that the consumer's love for Kaskus brand has decreased as well.

Table 2. Kaskus Position in the Top Brand Trading

\begin{tabular}{|l|l|l|}
\hline \multicolumn{1}{|c|}{ Year } & Position & \multicolumn{1}{c|}{ Persentage } \\
\hline 2012 & 2 & $15,6 \%$ \\
\hline 2013 & 2 & $18,4 \%$ \\
\hline 2014 & 3 & $4,5 \%$ \\
\hline 2015 & 4 & $0,9 \%$ \\
\hline 2016 & 5 & $0,8 \%$ \\
\hline 2017 & 12 & $0,5 \%$ \\
\hline 2018 & 34 & $0,4 \%$ \\
\hline
\end{tabular}

Source: [10]

Brand love being affected by a high level of consumer satisfaction related to consumer behavior will affect high brand loyalty, especially to be involved in conducting positive word of mouth to various parties. Positive word of mouth used as a means of communication [11].

This theory explains the relationship of consumers with brands that are in the consumer's mind. Brand love is influenced by several factors, including brand relationship [12], brand loyalty, brand experience [13], brand image [14], brand trust [15], brand identification, and sense of community [16].

The purposes of this study are: (1) To determine the magnitude of the influence of brand identification on brand love (2) to determine the magnitude of the influence of sense of community on brand love.

\subsection{Brand Love}

Since it was introduced by [5], brand love has become a very interesting topic for brand managers. Customers can see the brand as an individual, so they can love the brand as much as they love someone. On the basis of [17] conceptualization of interpersonal love, the relationship between consumers and a shared brand is divided into three dimensions: desire, longing, and decision or commitment, which is in accordance with intimacy, passion, and decisions or components of interpersonal love commitment.
Marketing researchers have investigated the concept of brand love [18]. Reference [19] answers the question whether consumers can experience feelings of love for a brand.

Brand love in this study will be measured by several dimensions proposed by [20]:

- Passion for a brand

- Brand attachment

- Positive evaluation of the brand

- Positive emotions in response to the brand

- Declarations of love toward the brand

\subsection{Brand Identification}

Consumers who choose products and brands are not only for their utilitarian values but also for symbolic benefits. The brand has a deep meaning [21] and serve to build consumers' self-concept or identity.

According to a research conducted by [20], it explained several dimensions of brand identification namely:

- Having a good support for the company goals brand

- Protecting its reputation

- Supporting its products to be the driving force for the company.

\subsection{Sense of Community}

The community psychology literature in the Sense of Community (SOC) provides a basis for understanding individual identity as well as intrarelationship and interrelationships. The study is based on the SOC concept which emphasizes individual feelings towards the community by elucidating feelings of belonging [22].

According to [23], someone will gain a sense of community when they feel the four dimensions in a community, which are as follows:

- Membership

- Influence

- Integration

- Fulfillment of needs

\section{METHODS}

The population in this study was KaskusTrading forum community, and it was about 351 people who had active account. The sampling technique of the study 
used was a non-probability sampling technique by using a Tabanick formula with 107 sample respondents. Then, the data collection techniques used was literature study and questionnaire distribution using multiple linear regression analysis

\section{RESULTS AND DISCUSSION}

The multiple linear regression equation model formed in this study is can be seen in (1)

$\mathrm{Y}=\mathrm{b}_{0}+\mathrm{b}_{1} \mathrm{X}_{1}+\mathrm{b}_{2} \mathrm{X}_{2}$

Source: [24]

$$
\begin{aligned}
\mathrm{Y} & =\text { Brand Love } \\
\mathrm{X} 1 & =\text { Brand identification } \\
\mathrm{X} 2 & =\text { Sense of community } \\
\mathrm{a} & =\text { Constant number } \\
\mathrm{b} 1,2 & =\text { Regression coefficient } \\
\mathrm{e} & =\text { Standart error }
\end{aligned}
$$

\begin{tabular}{|c|c|c|c|c|c|}
\hline \multicolumn{6}{|c|}{ Coefficients $^{\mathrm{a}}$} \\
\hline \multirow{2}{*}{ Model } & \multicolumn{2}{|c|}{$\begin{array}{c}\text { Unstandardized } \\
\text { Coefficients }\end{array}$} & \multirow{2}{*}{\begin{tabular}{|c}
$\begin{array}{c}\text { Standardized } \\
\text { Coefficients }\end{array}$ \\
Beta \\
\end{tabular}} & \multirow{2}{*}{$T$} & \multirow{2}{*}{ Sig. } \\
\hline & $\boldsymbol{B}$ & $\begin{array}{c}\text { Std. } \\
\text { Error }\end{array}$ & & & \\
\hline 1 (Constant) & 19,305 & 5,755 & & 3,355 & 001 \\
\hline Brand Identification & 670 &, 200 & 312 & 3,352 & 001 \\
\hline Sense of Community & 1,046 &, 186 &, 524 & 5,629 & 000 \\
\hline
\end{tabular}

By using SPSS 24.0 for Windows program, the regression coefficient results are obtained in Table 3.

Table 3. Regression Coefficients

Dependent Variable: Brand Love

Source: SPSS 24.0 for Windows 2020

Based on the above output, the values of constants and regression coefficients is found, so that the multiple linear regression equation can be formed as can be seen in (2).

$\mathrm{Y}=19,305+0,670 \mathrm{X} 1+1,046 \mathrm{X} 2$

Equation (2) can be interpreted as follows:

- $\quad \mathrm{a}=19,305 \quad$ : it means that if the variable brand identification, sense of community, is zero (0), then Brand Love will be 19.305.

- $\mathrm{b}_{1}=0,670 \quad$ : it means that if brand identification increases by one unit and other variables are constant, then Brand Love will decrease by 0.670 .

- $\mathrm{b}_{2}=1,046 \quad:$ it means that if the sense of community increases by one unit and the other variables are constant, then Brand Love will decrease by 1,046 .

\subsection{Correlations Analysis}

By using SPSS 24.0 for Windows application program, the output of correlation coefficient estimation results is obtained in Table 4.

Table 4. Correlation Coefficient Model Summary

\begin{tabular}{|l|c|l|l|l|}
\hline \multicolumn{5}{|c|}{ Model Summary } \\
\hline Model & $\boldsymbol{R}$ & $\boldsymbol{R}$ Square & $\begin{array}{c}\text { Adjusted } \boldsymbol{R} \\
\text { Square }\end{array}$ & Std. Error of the Estimate \\
\hline 1 &, $787^{\mathrm{a}}$ &, 620 &, 613 & 5,104 \\
\hline
\end{tabular}

Predictors: (Constant), Sense of Community, Brand Identification

Dependent Variable: Brand Love

Source: SPSS 24.0 for Windows 2020

According to the analysis, it can be seen that the correlation coefficient $(\mathrm{R})$ is 0.787 .

\subsection{Coeficients Partial Analysis}

The results show that the $R$ value is 0.787 , then the coefficient of determination can be calculated using (3).

$\mathrm{CD}=\mathrm{r}^{2} \times 100 \%$

Source: [25]

Information:

CD : Coefficient of determination

r2 : Correlation coefficient

100\%: Constant

The influence of brand identification on brand love can be seen from the results of Table 5 .

Table 5. Coeficient Partial

\begin{tabular}{|l|c|l|l|l|l|}
\hline \multicolumn{7}{|c|}{ Model Summary } \\
\hline Model & $\boldsymbol{R}$ & $\begin{array}{c}\boldsymbol{R} \\
\text { Square }\end{array}$ & $\begin{array}{c}\text { Adjusted } \boldsymbol{R} \\
\text { Square }\end{array}$ & $\begin{array}{c}\text { Std. Error of the } \\
\text { Estimate }\end{array}$ & $\begin{array}{c}\text { Durbin- } \\
\text { Watson }\end{array}$ \\
\hline 1 & $, 710 \mathrm{a}, 504$ &, 500 & 5,803 & 2,206 \\
\hline
\end{tabular}

Predictors: (Constant), Brand Identification

Dependent Variable: Brand Love

Source: SPSS 24.0 for Windows 2020

$$
\begin{gathered}
C D=r 2 \times 100 \% \\
=(0,710) 2 \times 100 \% \\
=50.4 \%
\end{gathered}
$$

The CD value is about $50.4 \%$, which shows that brand identification has a partial influence of $50.4 \%$ on brand love. While the remaining $49.1 \%$ is influenced by factors that are not examined in this study, such as brand relationship [26], brand loyalty, brand experience [13], brand image [14], brand trust [15], brand identification, and sense of community [16]

The influence of sense of community on brand love can be seen from the results shown in Table 6 . 
Table 6. Partial Determination Coefficients

\begin{tabular}{|l|c|c|c|c|c|}
\hline \multicolumn{6}{|c|}{ Model Summary $^{\mathbf{b}}$} \\
\hline Model & $\boldsymbol{R}$ & $\begin{array}{c}\boldsymbol{R} \\
\text { Square }\end{array}$ & $\begin{array}{c}\text { Adjusted } \boldsymbol{R} \\
\text { Square }\end{array}$ & $\begin{array}{c}\text { Std. Error of the } \\
\text { Estimate }\end{array}$ & $\begin{array}{c}\text { Durbin- } \\
\text { Watson }\end{array}$ \\
\hline 1 &, $761^{\mathrm{a}}$ &, 579 &, 575 & 5,348 & 2,130 \\
\hline
\end{tabular}

Predictors: (Constant), Sense of Community

Dependent Variable: Brand Love

Source: SPSS 24.0 for Windows 2020

$$
\begin{gathered}
C D=r 2 \times 100 \% \\
=(0,761) 2 \times 100 \% \\
=57.91 \%
\end{gathered}
$$

\subsection{Simultaneous Hypothesis Testing (Test F)}

This test was carried out to see the significance of the influence of brand identification and sense of community on brand love. The $\mathrm{F}$ test formula or

\begin{tabular}{|c|c|c|c|c|c|}
\hline \multicolumn{6}{|c|}{ ANOVA $^{a}$} \\
\hline Model & Sum of Squares & $D f$ & Mean Square & $\boldsymbol{F}$ & Sig. \\
\hline 1 Regression & 4421,956 & 2 & 2210,978 & 84,857 &, $000 \mathrm{~b}$ \\
\hline Residual & 2709,764 & 104 & 26,055 & & \\
\hline Total & 7131,720 & 106 & & & \\
\hline
\end{tabular}
ANOVA test is explained in the following Table 7.

Table 7. Test Significance Value F

Dependent Variable: Brand Love

Predictors: (Constant), Sense of Community, Brand Identification Source: SPSS 24.0 for Windows 2020

\subsection{Partial Hypothesis Testing (t Test)}

The test was carried out to find out the percentage of the effect of brand identification and sense of community on brand love. Therefore, this study used SPSS 24.0 for windows, and the following output can be seen in Table 8.

According to the results of the t-test, it can be concluded that the hypothesis $\mathrm{HO}$ is rejected and $\mathrm{Ha}$ is accepted. Therefore, the explanation is as follows:

- There was a significant influence of brand identification on brand love in Kaskus trading forum.

- There was a significant influence of sense of community on brand love in Kaskus trading

\begin{tabular}{|c|c|c|c|c|}
\hline \multicolumn{5}{|c|}{ Coefficients $^{\mathrm{a}}$} \\
\hline \multirow[b]{2}{*}{ Model } & \multicolumn{2}{|c|}{$\begin{array}{c}\text { Unstandardized } \\
\text { Coefficients }\end{array}$} & \multirow{2}{*}{$\begin{array}{c}\begin{array}{c}\text { Standardized } \\
\text { Coefficients }\end{array} \\
\text { Beta } \\
\end{array}$} & \multirow[b]{2}{*}{$t \quad$ Sig. } \\
\hline & $\boldsymbol{B}$ & Std. Error & & \\
\hline 1 (Constant) & 19,305 & 5,755 & & $3,355,001$ \\
\hline $\begin{array}{l}\text { Brand } \\
\text { Identification }\end{array}$ & ,670 & ,200 & ,312 & $3,352,001$ \\
\hline $\begin{array}{l}\text { Sense of } \\
\text { Community }\end{array}$ & 1,046 & , 186 & ,524 & $5,629,000$ \\
\hline
\end{tabular}
forum.

Table 8. Significance Value of Test T

Dependent Variable: Brand Love

Source: SPSS 24.0 for Windows 2020.

\section{CONCLUSION}

Based on the discussion of theory, results, and multiple regression analysis testing conducted on the influence of brand identification and sense of community on Brand Love in FJB Kaskus community in Bandung, it can be concluded that brand identification had a positive influence on brand love. It shows that the better brand identification, the lower the brand loves on FJB Kaskus users in Bandung. In addition, the sense of community had a positive effect on brand love. It shows that the better the sense of community, the lower the brand loves for FJB Kaskus users in Bandung.

\section{REFERENCES}

[1] V. Baena, "Online and mobile marketing strategies as drivers of brand love in sports teams Findings from Real Madrid,” Int. J. Sport. Mark. Spons., vol. 17, no. 3, pp. 202-218, 2016.

[2] S. A. \& S. H. A. Sæther;, "The impact of social networks in the development of a personal sports brand," 2014.

[3] K. Cortsen and K. Cortsen, "“.'Renstam - a hybrid Annika So personal sports brand," 2013.

[4] I. Abosag, S. Roper, and D. Hind, "Examining the relationship between brand emotion and brand extension among supporters of professional football clubs," vol. 46, no. 9, pp. 1233-1251, 2012.

[5] T. A. Shimp and T. J. Madden, "Consumer-object relations: A conceptual framework based analogously on Sternberg's Triangular Theory of Love," Adv. Consum. Res., 1988.

[6] J. I. Norris, D. L. Wann, and R. K. Zapalac, "Sport fan maximizing: following the best team or being the best fan?," J. Consum. Mark., vol. 32, no. 3, pp. 157-166, 2015.

[7] Alexa, 2019, Accessed: 21st October 2019. [Online]. Available: http://www.alexa.com.

[8] Startup Ranking, 2019, Accessed: 21st October 2019. [Online]. Available: http://www.startupranking.com.

[9] U. Kingdom, M. A. Sallam, S. Arabia, N. A. Wahid, and C. Network, "The effect of satisfication and brand identification on brand love and brand equity," vol. III, no. 2, pp. 1-13, 2015.

[10] Top Brand Awards, 2019, Accessed: 21st October 2019. [Online]. Available http://www. topbrandawards.com.com.

[11] D. M. Evans and A. C. T. Smith, "Internet sports marketing and competitive advantage for professional sports clubs: Bridging the gap between theory and practice," Internet Sport. Mark. Compet. Advant. Prof. Sport. clubs Bridg. gap between theory Pract., vol. 6, no. 2, pp. 86-98, 2004. 
[12] S. M. Hegner, "Using the theory of planned behaviour to understand brand love," 2017.

[13] J. Yao, X. Wang, and Z. Liu, "Brand management innovation: a construction of brand experience identification system,” J. Appl. Sci., vol. 13, no. 21, pp. 4477-4482, 2013.

[14] A. Sarkar, "Brand love in emerging market: a qualitative investigation," 2014.

[15] N. Albert, E. Management, and D. Merunka, "The role of brand love in consumer-brand relationships," no. 1988, 2013.

[16] J. W. Lyu, "The role of sense of community in online brand social networking sites," 2012.

[17] R. J. Sternberg, "A Triangular Theory of Love," Psychol. Rev., 1986.

[18] A. Rageh, "Journal of Fashion Marketing and Management: An International Article information," 2012.

[19] S. Fournier, "Consumers and their brands: Developing relationship theory in consumer research," J. Consum. Res., 1998.
[20] M. A. Sallam, "The effects of brand image and brand identification on brand love and purchase decision making: the role of WOM," International business research, vol. 7, no. 10, pp. 187, 2014.

[21] S. Roy, "To use the obvious choice: investigating the relative effectiveness of an overexposed celebrity," pp. 41-69, 2012.

[22] M. S. Rosenbaum, A. L. Ostrom, and R. Kuntze, "Loyalty programs and a sense of community," J. Serv. Mark., 2005.

[23] D. W. McMillan and D. M. Chavis, "Sense of community: A definition and theory," J. Community Psychol., 1986.

[24] Sugiyono, "Metode Penelitian Kuantitatif, Kualitatif dan R\&D," Bandung: PT Alfabet, 2017.

[25] Akdon and Riduwan, "Rumus dan Data dalam Analisis Statistika," in Bandung: Alfabeta, 2013.

[26] S. M. Hegner, A. Fenko, and A. Teravest, "Using the theory of planned behaviour to understand brand love," J. Prod. Brand Manag., 2017. 